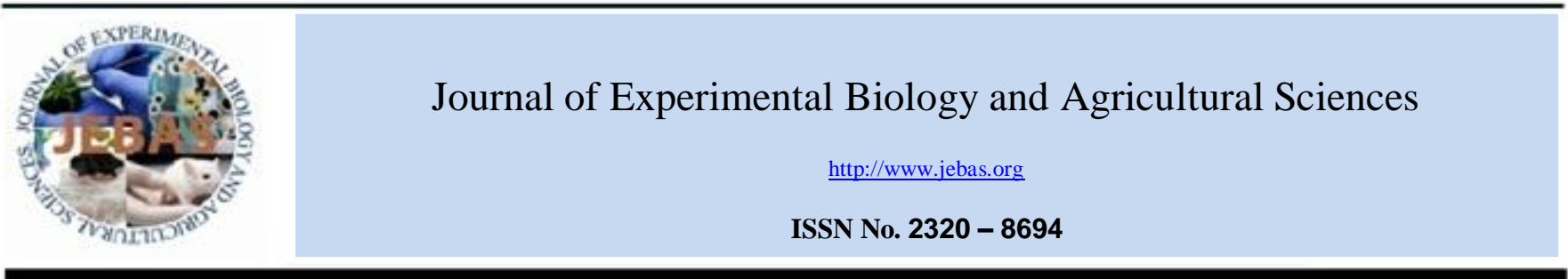

\title{
SYNTHESIS, CHARACTERIZATION AND APPLICATION OF CHITOSAN- G- ACRYLAMIDE COMPOSITE ON SOILS OF GANGETIC PLAIN REGION
}

\author{
Priyal Pandey ${ }^{1 *}$, Mahendra Kumar Verma ${ }^{1}$, Nirmal De $^{2}$ \\ Department of Soil Science and Agricultural Chemistry, Institute of Agricultural Sciences, Banaras Hindu University, Varanasi, Uttar Pradesh- 221005
}

Received - February 15, 2019; Revision - May 14, 2019; Accepted - June 04, 2019

Available Online - June 10, 2019

DOI: http://dx.doi.org/10.18006/2019.7(3).255.265

KEYWORDS
Chitosan
Acrylamide
Composite
Characterization
Soil
Incubation

\begin{abstract}
The present study was formalized to address the effect of chitosan-grafted polyacrylamide composite on soil and therefore an innovative eco-friendly chitosan-based composite was synthesized and its probable effect on soil chemical and biological properties were analyzed. Chitosan grafted polyacrylamide composite has been synthesized in the Department of Soil Science and Agricultural Chemistry, Institute of Agricultural Sciences, Banaras Hindu University. Synthesized Chitosan grafted polyacrylamide was characterized by Fourier transformation infrared (FTIR) spectroscopy, X-ray diffraction (XRD), Scanning electron microscopy (SEM) and Atomic force microscopy (AFM). Composite showed rough morphology with an average roughness $26.17 \mathrm{~nm}$, found to be partially amorphous with the presence of functional group from both acrylamide and chitosan. A lab incubation study for six months revealed that synthesized composites addition in soils (Alfisol and Inceptisol) of Gangetic plain region significantly increased soil electrical conductivity (EC), cation exchange capacity (CEC), catalase activity, dehydrogenase activity, and soil microbial biomass carbon content. Composite addition in soil did not altered soil pH, acid phosphatase activity, alkaline phosphatase activity and only urease activity in soil was found to be decreased during the incubation period. The implication of information about the effect of composite addition on soil properties is crucial for its usage and application in the soil system. This valuable information might be helpful in promoting more effective use of biopolymer-based composite rather than acrylate based composite in agriculture as a slow release carrier of fertilizers and water in the soil.
\end{abstract}

* Corresponding author

E-mail: piu.pandey89@gmail.com (Priyal Pandey)

Peer review under responsibility of Journal of Experimental Biology and Agricultural Sciences.

Production and Hosting by Horizon Publisher India [HPI] (http://www.horizonpublisherindia.in/).

All rights reserved.
All the articles published by Journal of Experimental Biology and Agricultural Sciences are licensed under a Creative Commons Attribution-NonCommercial 4.0 International License Based on a work at www.jebas.org.

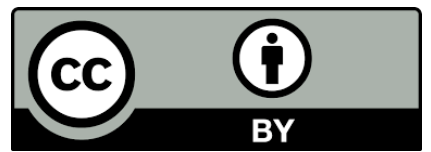




\section{Introduction}

Superabsorbent are hydrophilic, acrylate based, crosslinked structure capable of absorbing large amount of water and have distinct properties to improve soil water holding capacity, reduce drought stress, increase seed sprouting, reduce irrigation frequency and act as best carrier of water, fertilizer and pesticides to plants. Most of the superabsorbent used today are generally synthetic, application of which can have adverse effect on soil. Blooming with modern technology which can boost up the food production without hampering the harmony in ecosystem is the need of present time. In this context with increasing awareness on environmental issues, biodegradable superabsorbent catches interest for potential commercial application in agriculture (Cannazza et al., 2014). Superabsorbent prepared with natural materials, such as cellulose (Bao et al., 2011), starch (Bai et al., 2015), guar gum (Wang et al., 2009, Thombare et al., 2018), rice husk (Francisco et al., 2012) and chitosan(Said et al., 2018), have attracted great attention because of their abundant resources, low production-cost and biodegradability. Chitosan is a hydrophilic polysaccharide produced by partial deacetylation of chitin, it is second most abundant polysaccharide next to cellulose. Chitosan posses valuable properties as biocompatibility, biodegradability, non toxicity, amino and hydroxy group that are convenient for graft polymerization which popularize its use in agriculture sector (Harrar \& Dairi, 2013; Cheng et al., 2017). It has been used as a carrier for fertilizer, pesticides, medicines delivery. While research interest in superabsorbent is increasing, the current level of knowledge does not allow a fair assessment of the pros and cons that will arise from the superabsorbent use in agriculture. As a prerequisite for such an assessment, a better understanding of the fate and effect of superabsorbent products after their application is required. The present study was formulized to address the effect of superabsorbent composite on soil and therefore an innovative eco-friendly chitosan-based superabsorbent was synthesized and its probable effect on soil chemical and biological properties were analyzed in this paper.

\section{Materials and Methods}

Chitosan (CTS, 75\% degree of deacetylation and medium average molecular weight, viscosity, 200-800cps), acrylamide (AAm), ammonium persulfate (APS), and N-N'- methylene bisacrylamide (MBA), purchased from Hi-Media company (India) were used for superabsorbent composite preparation. All reagents used were of analytical grade, and all solutions were prepared with quartz distilled water.

\subsection{Synthesis of chitosan-based composite}

For the preparation of chitosan-based composite, method of Harrar et al. (2014) was followed. For this, one g (20 wt \%) of chitosan (CTS) was dissolved in $30 \mathrm{ml}(\mathrm{v} / \mathrm{v})$ acetic acid solution in a $250 \mathrm{ml}$ three-necked flask, equipped with a reflux condenser, a funnel, a nitrogen line, and a magnetic stirrer. Then $0.1 \mathrm{~g}(2 \mathrm{wt} \%)$ of APS was added to the CTS solution and the resulting mixture was gently stirred for 15 minutes at $60^{\circ} \mathrm{C}$ to generate free radicals. The aqueous mixed solution of acrylamide and MBA added to the flask containing chitosan solution. The solution was stirred vigorously for another 3 hours and a nitrogen atmosphere was maintained all through the polymerization reaction. After the polymerization reaction hydrogel composite was formed. The synthesized products were immersed in an excess of double distilled water, washed repeatedly and then dewatered with $500 \mathrm{ml}$ of methanol for 24 h. Composite was then dried in an oven at $65^{\circ} \mathrm{C}$ to a constant weight. Finally, the product was ground (particles size in the range of 40-60 mesh) and stored away from moisture, heat and light. The mechanism of composite preparation was shown in figure 1 and setup for the preparation of superabsorbent composite was shown in figure 2 (Table 1)..

\subsection{Characterization of chitosan grafted superabsorbent}

\subsubsection{FTIR Analysis}

Infrared spectroscopy (IR) of the powdered samples of chitosan and synthesized polymer composite was carried out by Perkin spectra 2 spectrophotometers. Superabsorbent samples were scanned in the region of $4000-400 \mathrm{~cm}^{-1}$ using $\mathrm{KBr}$ pellets. All the spectra were recorded and analyzed to know the type and nature of the functional group attachment in chitosan and synthesized composite

Table 1 Properties of Chitosan based superabsorbent

\begin{tabular}{|lc|}
\hline Properties & $\begin{array}{c}\text { Chitosan based } \\
\text { superabsorbent }\end{array}$ \\
\hline $\mathrm{pH}$ & 6.8 \\
\hline Size $(\mathrm{mm})$ & 0.5 \\
\hline Water uptake capacity & \\
\hline Distilled water $(\mathrm{g} / \mathrm{g})$ & 156.7 \\
\hline Tap water $(\mathrm{g} / \mathrm{g})$ & 96.55 \\
\hline & \\
\hline
\end{tabular}




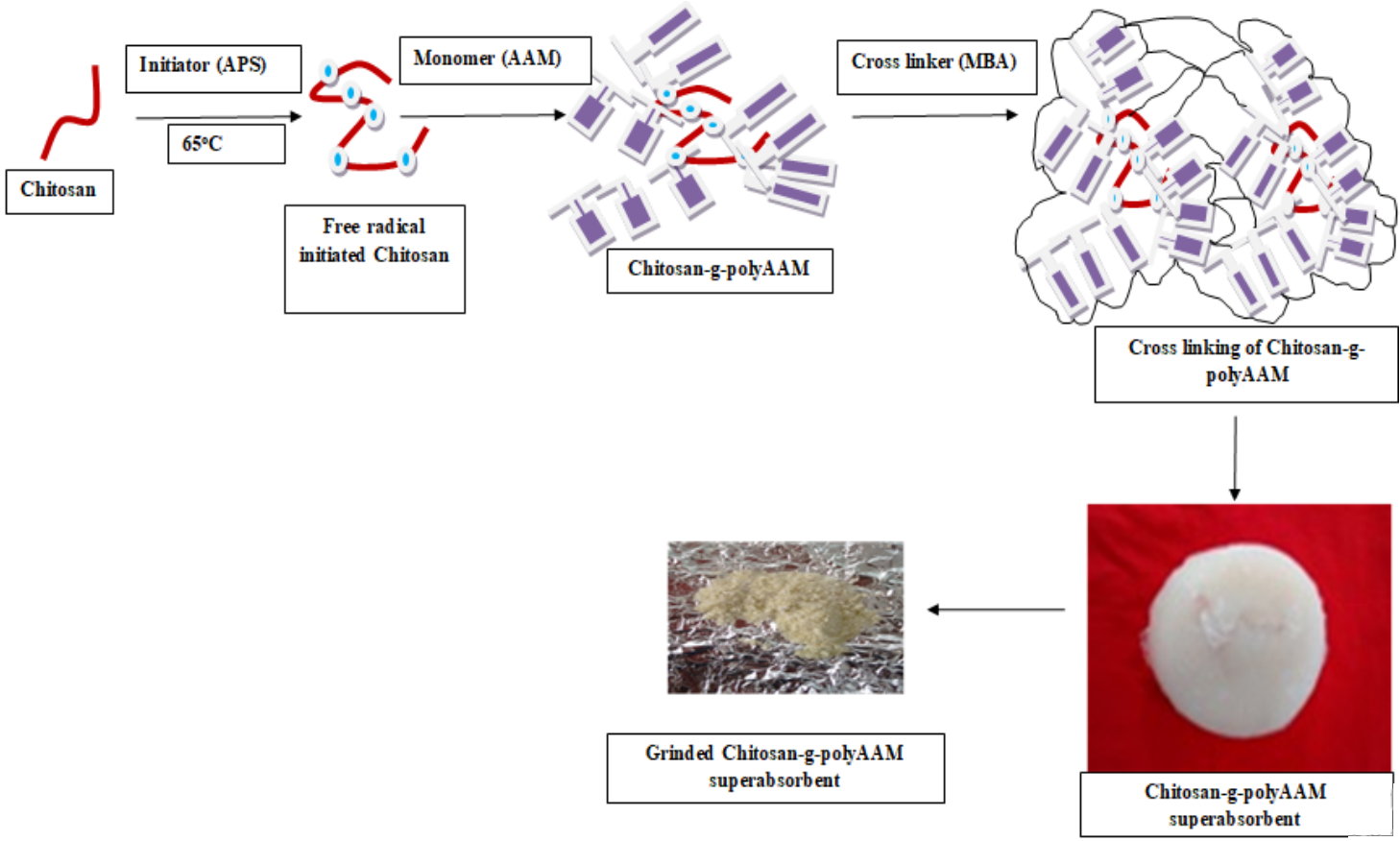

Figure 1 Mechanism of preparation of superabsorbent composite

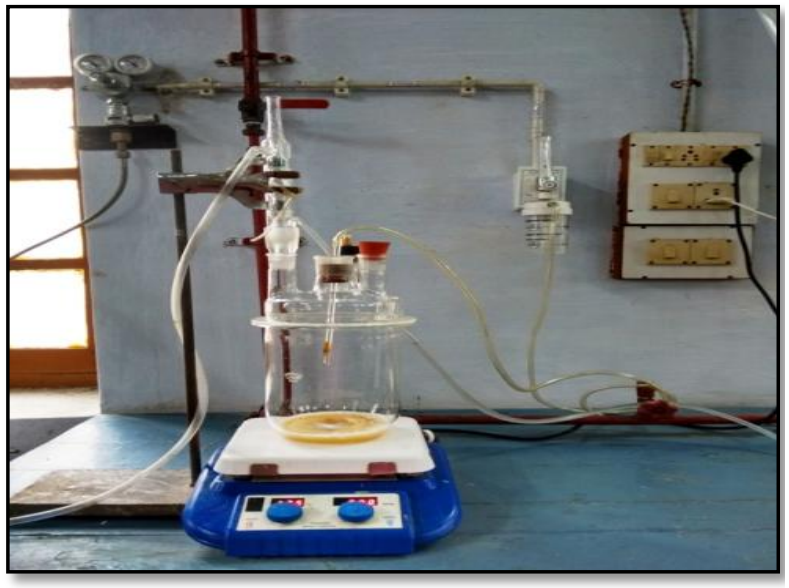

Figure 2 Reaction setup for preparation of chitosan-g-acrylamide composite

\subsubsection{XRD}

XRD patterns of the chitosan and synthesized composite were recorded by X-ray diffractometer (XRD, Bruker D8 Advance Eco), USA using $\mathrm{Cu}-\mathrm{K} \alpha$ radiation $\left(\mathrm{k}=1.54 \mathrm{~A}^{\circ}\right)$ within 3 to 80,2 theta range. XRD is a non-destructive method for characterization of crystalline compounds. XRD was obtained with X-ray tube having
Cu-anode (Philips) running at $40 \mathrm{kV}$ and $20 \mathrm{~mA}$, scanning from $3^{\circ}$ to $50^{\circ}$ using APD (automated powder diffraction) software with the following setting of the instrument: Radiation type-Cu-Ka. Sample holder made up of aluminum. The samples were cleaned with acetone solution and filled in the space defined for the specimen. The specimen holder was inserted in the X-ray diffractometer for the analysis of the randomly oriented sample.

\subsubsection{SEM}

Scanning electron micrographs (SEM) produced the morphological image of superabsorbent by an electron beam and was recorded on the Zeiss EVO 18 (SEM) instrument. The accelerating voltage used was $15 \mathrm{kV}$ and the applied magnification of the image was $5000 \mathrm{X}$. It provides information about the morphology of synthesized chitosan grafted composite.

\subsubsection{Atomic Force Microscopy}

The surface morphology, roughness were further examined by atomic force microscopy (NT-MDT SOLVER AFM/STM). AFM images were analyzed using Nova Image Analysis 2.0software. For the AFM studies, chitosan-grafted composite was immobilized on glass slide by cutting thin section of hydrated superabsorbent, put it on glass slide cover it with cover slip, and subjected to image analysis. 


\subsection{Lab incubation experiment}

Alluvial soil from agricultural research farm of Banaras Hindu University and Red soil from Rajiv Gandhi South Campus Barkachha, Mirzapur was taken for lab incubation study. A 180 days lab incubation experiment was conducted to analyze the effect of various contact times between superabsorbent and soil on the chemical properties and enzymatic activity of red and alluvial soil. For this study soil samples were pre-incubated in the dark at $25 \pm 1^{\circ} \mathrm{C}$ for seven days to stabilize microbial activity later $0.1 \%$ weight of superabsorbent was added to pre-incubated soil and observations were taken after 1 day, 30 days,90 days and 180 days. The results were compared with control samples in which superabsorbent was not added. Each treatment had three replicates. The soil water-holding capacity (WHC) was adjusted to $50 \%$ before incubation. Throughout the experiments, soil moisture was maintained at a constant level of $50 \%$ WHC using WET sensor (soil moisture sensor, Vernier).

\subsection{Soil chemical properties}

The $\mathrm{pH}$ of the soil was determined by using a $\mathrm{pH}$ meter (Mettler Toledo, Systronics, Gujarat, India), organic carbon by titration method (Walkley \& Black, 1934) and cation-exchange capacity (CEC) was determined using sodium acetate solution ( $\mathrm{pH}$ 8.2) with the help of centrifuge as described by Jackson (1973).

\subsection{Enzyme activity analysis}

In the present experiment, the activity of five enzymes (dehydrogenase, urease, acid,and alkaline phosphatases and catalase) was estimated as mentioned below.

\subsubsection{Dehydrogenase activity}

For estimating dehydrogenase activity $1 \mathrm{~g}$ of air-dried soil was kept in an airtight screw-capped test tube ( $15 \mathrm{~mL}$ capacity). 0.5 $\mathrm{mL}$ of $1 \%$ glucose solution was added in each tube. The bottom of the tube was gently tapped to drive out all trapped oxygen, and thus a water seal was formed above the soil. $0.2 \mathrm{~mL}$ of $1 \%$ glucose solution in each of the tubes was added to saturate the soil. The tube was incubated at $28^{\circ} \mathrm{C}$ for 24 hours. After incubation $10 \mathrm{~mL}$ of methanol was added and shook vigorously and allowed to stand for $6 \mathrm{~h}$. Clear pink colored supernatant was withdrawn and reading was taken with a spectrophotometer at a wavelength of $485 \mathrm{~nm}$ (blue filter) (Casida et al.,1964).

\subsubsection{Urease activity}

Five grams of soil sample was treated with $5 \mathrm{~mL}$ of urea solution in a glass vial/conical flask. The bottle was capped and incubated at $37^{\circ} \mathrm{C}$. After 5 hours the cap was removed and $50 \mathrm{~mL}$ of $2 \mathrm{M} \mathrm{KCl-PMA}$ solution was added. After addition of KCl-PMA solution bottles were again capped and shaken. After one hour the solution was filtered through Whatman no. 42 filter paper. One or two $\mathrm{mL}$ of the aliquot was taken into $50 \mathrm{~mL}$ volumetric flask. Volume was made up to 10 $\mathrm{mL}$ with $2 \mathrm{M} \mathrm{KCl-PMA}$ solution, and $30 \mathrm{~mL}$ of coloring reagent was added. The flask was swirled for a few seconds and placed in a bath of boiling water. After keeping it for 30 minutes on the water bath, the flasks were removed and cooled immediately in cold water for 15 min. Volume was made to $50 \mathrm{~mL}$ with water and mixed thoroughly. The absorbance of red color developed was measured at $527 \mathrm{~nm}$ using spectrophotometer (McGarity \& Myers, 1967).

\subsubsection{Acid and alkaline phosphatase in soil}

Two grams of soil was taken in two $50 \mathrm{~mL}$ conical flask. Out of these two sets, one was used as a control. $0.2 \mathrm{~mL}$ toluene and 4 $\mathrm{mL}$ of MUB (pH 6.5 for acid phosphatase and $\mathrm{pH} 11$ for alkaline phosphatase) was added to all flasks and add $1 \mathrm{~mL}$-nitrophenyl phosphate solution to only 1 set of samples. The flasks of both the sets were swirled for few seconds to mix the contents. They were closed with the help of stopper and placed in an incubator at $37^{\circ} \mathrm{C}$ for 1 hour. After incubation, the stoppers were removed and $1 \mathrm{~mL}$ of $0.5 \mathrm{M} \mathrm{CaCl}_{2}$ and $4 \mathrm{~mL}$ of $\mathrm{NaOH}$ was added. The flasks were swirled for a few seconds. $1 \mathrm{~mL}$ of $\mathrm{p}$ - nitrophenyl phosphate was added to the remaining (control) set of samples. Suspensions were filtered quickly through Whatman No. 2 filter paper. The yellow color intensity of the filtrate was measured with a blue filter at $440 \mathrm{~nm}$ (Chhonkar et al., 2007).

\subsubsection{Catalase activity in the soil}

Catalase activity was measured by back-titrating residual $\mathrm{H}_{2} \mathrm{O}_{2}$ with $\mathrm{KMnO}_{4}$. Two grams of soil samples were added to $40 \mathrm{~mL}$ distilled water with $5 \mathrm{~mL}$ of $0.3 \%$ hydrogen peroxide solution. The mixture was shaken for $20 \mathrm{~min}$ and then $5 \mathrm{~mL}$ of $1.5 \mathrm{~mol} / \mathrm{LH}_{2} \mathrm{SO}_{4}$ was added. Afterward the solution was filtered and titrated by using $0.02 \mathrm{~mol} / \mathrm{L}$ $\mathrm{KMnO}_{4}$ till pink endpoint appears. The reacted amount of $0.02 \mathrm{~mol} / \mathrm{L}$ $\mathrm{KMnO}_{4}$, calculated per gram of dry soil (Zhang et al., 2012), was used to express the activity of catalase.

\subsection{Soil microbial biomass Carbon}

Incubated soil weighed $20 \mathrm{~g}$ (dry weight equivalent) was taken into a glass beaker $(50 \mathrm{ml})$ and labeled (using masking tape and a pencil). In the desiccator, some wet paper were kept at the base to keep humidity up and to stop soil from drying out, then glass beakers with soil were kept in it and chloroform was kept in another beaker. Desiccator was sealed and a vacuum was applied so that the chloroform boils for about 2 minutes. Sealed desiccator was left for 5-10 minutes; afterward the vacuum was reapplied for a couple of minutes boiling (just to ensure good fumigation). Then desiccator was sealed and kept at $25{ }^{\circ} \mathrm{C}$ for $24 \mathrm{~h}$. The soil was extracted with $80 \mathrm{ml}$ of $0.5 \mathrm{M} \mathrm{K}_{2} \mathrm{SO}_{4}$ for $20 \mathrm{~g}$ fumigated soil. Soil microbial biomass carbon was analyzed by process of Jenkinson \& Ladd, (1981). 


\subsection{Statistical analysis}

Multivariate analysis was applied to compare the effect of incubation time and soil types on soil properties. The analysis was done by SPSS software (version 20 IBM, Chicago Inc, USA) using DMRT post hoc test.

\section{Results and Discussion}

\subsection{Characterization}

\subsubsection{FTIR analysis}

FTIR spectral analysis was carried out to confirm the formation of superabsorbent composite and in order to understand the chemical structure of chitosan-grafted acrylamide composite. The infrared spectra of chitosan and chitosan grafted acrylamide were shown in figure 3. It was observed that the most typical absorption band of $\mathrm{C}=\mathrm{O}$ chitosan was located at $1643 \mathrm{~cm}^{-1}$ due to partial deacetylation, and characteristic peak of the amino group was around $3416 \mathrm{~cm}^{-1}$, peak at $1385 \mathrm{~cm}^{-1}$ and $1089 \mathrm{~cm}^{-1}$ was due to N-H and C-O stretching which is a feature of polysaccharide. In IR spectra of chg-gacrylamide a peak at $1412 \mathrm{~cm}^{-1}$ was due to the $\mathrm{C}-\mathrm{N}$ stretching, which supported the occurrence of the grafting reaction. Furthermore, the appearance and intensification of the peaks at $1640 \mathrm{~cm}^{-1}$ and $1568 \mathrm{~cm}^{-1}$ for the primary $\mathrm{NH}_{2}$ groups confirmed that polyacrylamide chains grew on the chitosan backbone. The stretching peak at 3414 $\mathrm{cm}^{-1}$ shifted to a longer wave number (approximately $3428 \mathrm{~cm}^{-1}$ ) which was due to overlapping of $\mathrm{O}-\mathrm{H}$ stretching of chitosan and $\mathrm{N}-\mathrm{H}$ stretching of amide groups at poly acrylamide grafts (Kumar et al., 2012; Zhang et al., 2012; Harrar et al., 2014).

\subsubsection{XRD analysis}

The X-ray diffraction spectra for chitosan and chg-g-Paam superabsorbent were shown in figure 4. The X-ray diffractions of chitosan showed two crystalline peak at 11.86 and 19.94. However,

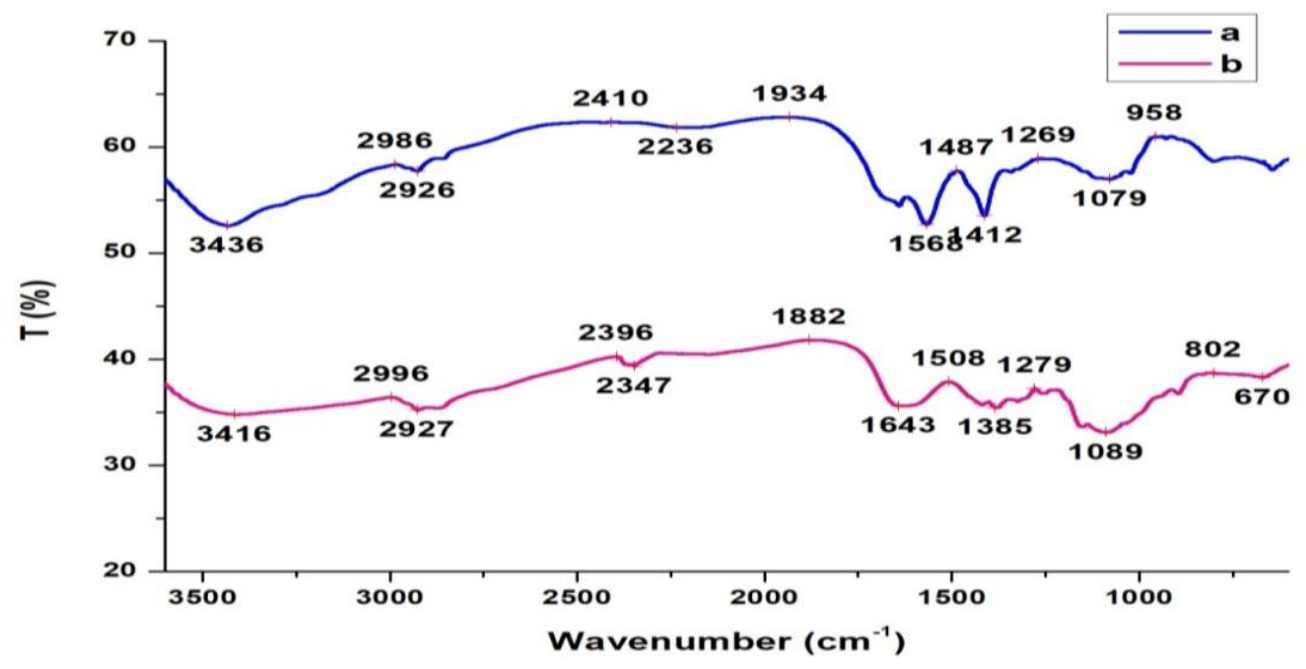

Figure 3 FTIR spectra of chitosan grafted acriamide composite (a) and chitosan (b)

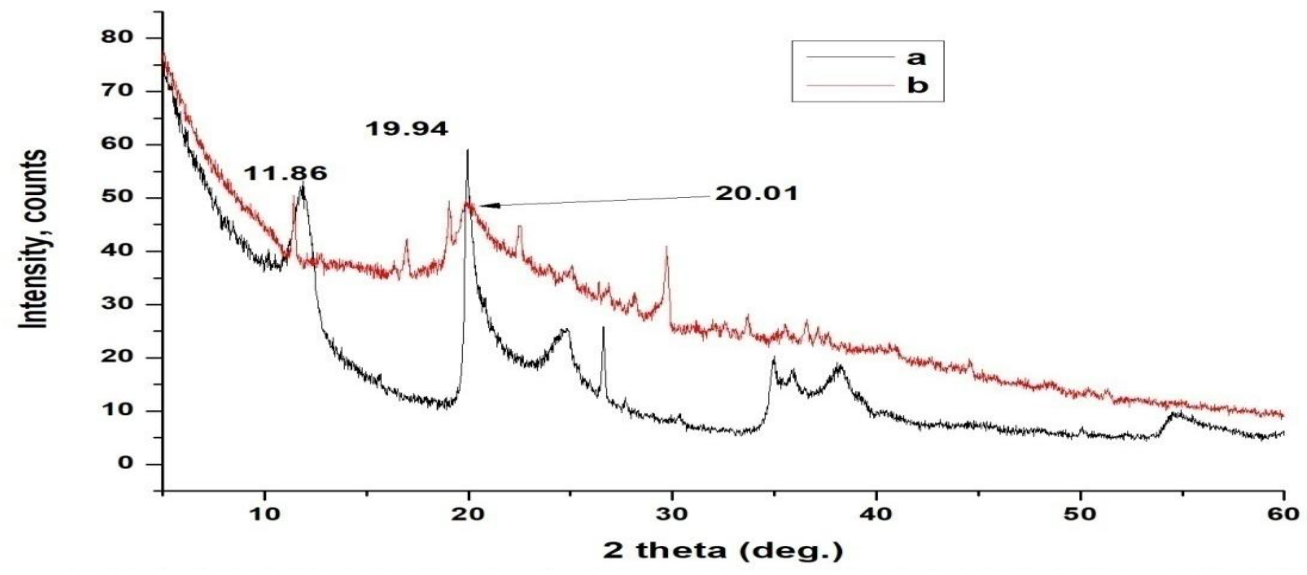

Figure 4 XRD of chitosan (a) and chitosan grafted acrlamide composite (b) 
the first peak began to disappear and the second peak appeared less intense in superabsorbent diffractogram. The reduction in crystallinity can be attributed to deformation of a hydrogen bond between $\mathrm{OH}$ and $\mathrm{NH}_{2}$ bond of chitosan. Grafting reaction proceeds initially in the amorphous region but as grafting increases crystallinity decreases leads to an increase in the amorphous region (Kumar et al., 2012; Samandari \& Gazi,2013). This indicated that the polyacrylamide chain has been grafted on chitosan.

\subsubsection{Morphological study by SEM and AFM}

Surface porosity of composites has great importance on swelling behavior of hydrogels. SEM micrographs of chitosan, the grafted network was shown in figure 5 and figure 6. Chg-g-paam network exhibits porous structure though no porosity is observed in chitosan structure. It was supposed that these pores were convenient for the penetration of water and were the sites for the

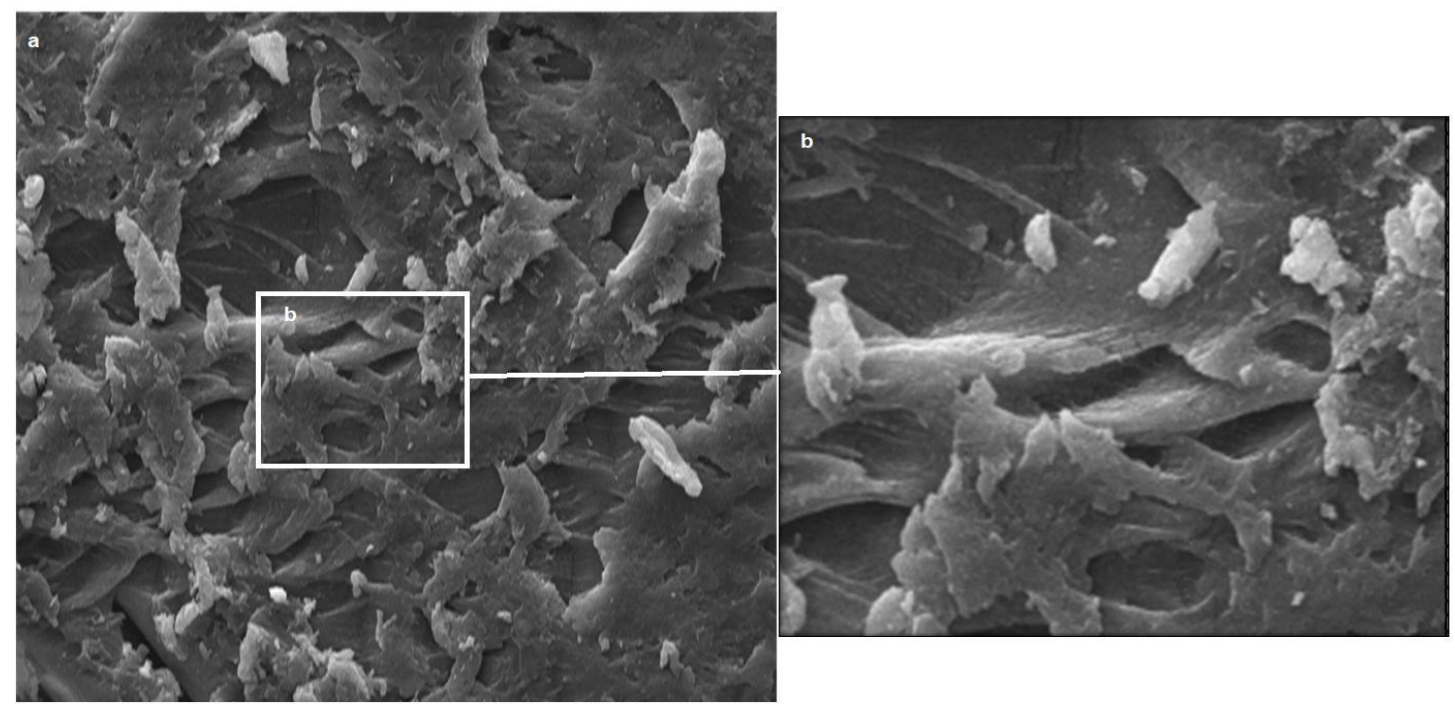

Figure 5 SEM of chitosan grafted acrylamide composite ( $a$ and $b$ )

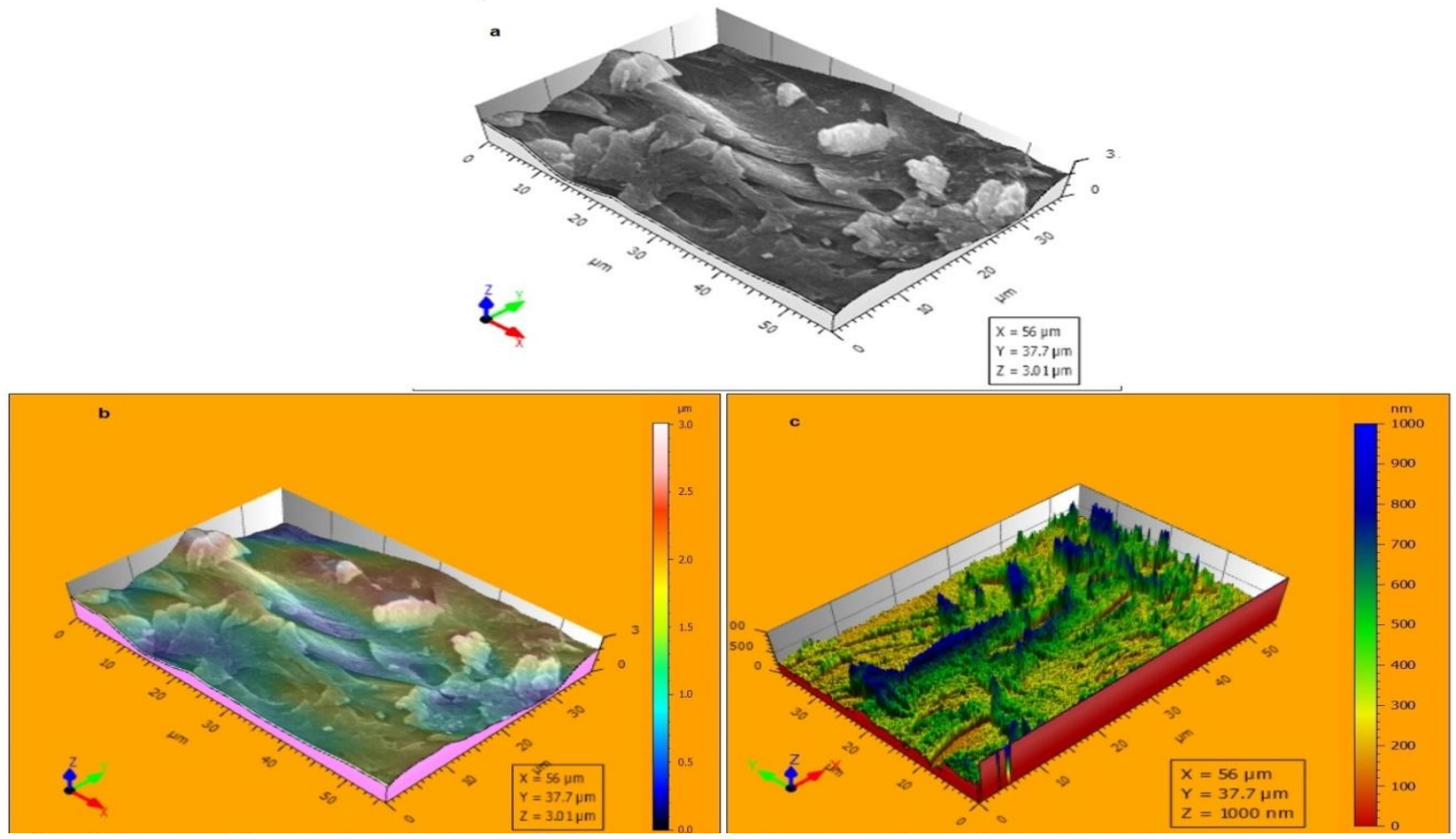

Figure 6 Three dimensional view of chitosan grafted acrylamide composite

Journal of Experimental Biology and Agricultural Sciences http://www.jebas.org 


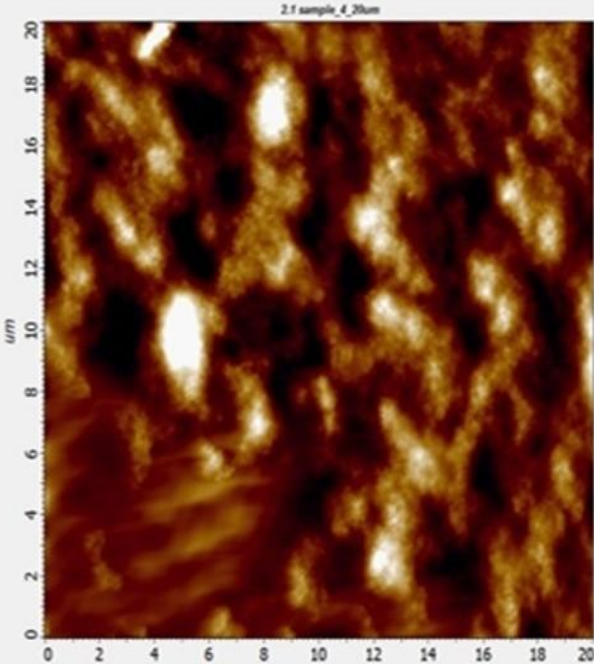

Fig. 7. AFM of chitosan grafted acrylamide composite in two dimensional (a) and three dimensional form (b)

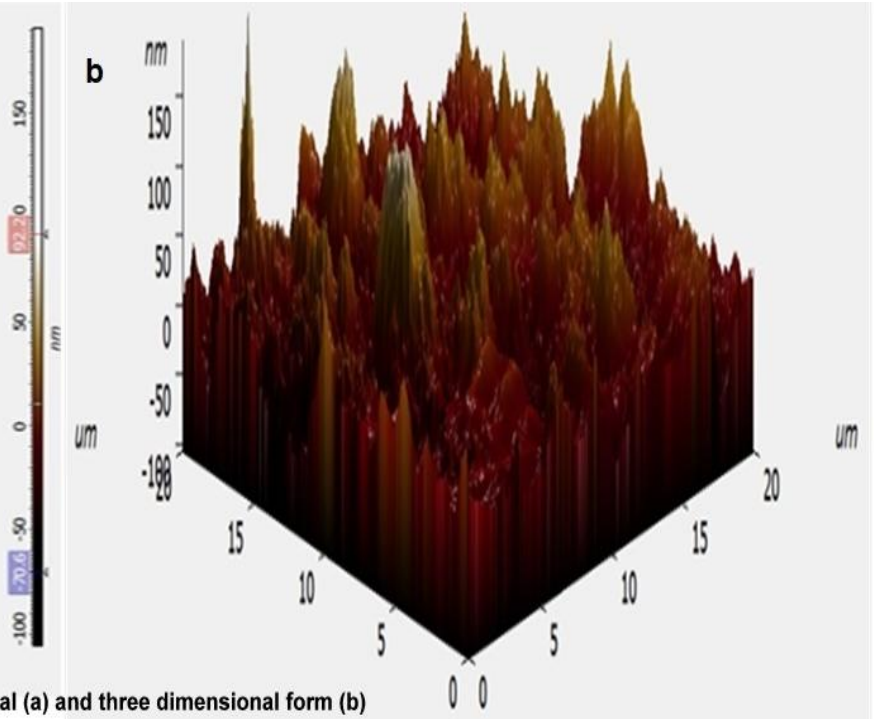

Table 2 Properties of soil used in study

\begin{tabular}{|ccc|}
\hline Soil Properties & Alluvial Soil & Red Soil \\
\hline $\mathrm{pH}$ & $7.67 \pm 0.27$ & $5.87 \pm 0.35$ \\
\hline $\mathrm{EC}\left(\mathrm{dSm}^{-1}\right)$ & $0.34 \pm 0.74$ & $0.19 \pm 0.41$ \\
\hline Organic Carbon $(\%)$ & $0.57 \pm 0.11$ & $0.37 \pm 0.24$ \\
\hline CEC $\left(\mathrm{cmol}\left(\mathrm{P}^{+}\right) \mathrm{kg}^{-1}\right.$ & $13.8 \pm 0.62$ & $8.30 \pm 0.51$ \\
\hline Water holding capacity $(\%)$ & $45.9 \pm 0.33$ & $37.7 \pm 0.84$ \\
\hline
\end{tabular}

interaction of external stimuli with the hydrophilic groups of the network (Harrar et al., 2015). The porosity of the hydrogels plays multiple rolesin enhancing the total water sorption capability and the rate of response by reducing the transport resistance. Hence, it is one of the most important properties that must be considered in the hydrogel structure.

AFM image of chitosan-grafted superabsorbent was presented in figure 7. AFM results were in agreement with the SEM result that chitosan grafted composite was porous and rough which helped in penetration of water and nutrients. Root mean square roughness of composite was $33.91 \mathrm{~nm}$, average roughness was $26.17 \mathrm{~nm}$ and area peak-to-valley height was $295.50 \mathrm{~nm}$. The result was in agreement with the result of Nagarpita et al. (2017). AFM result also depicts porous behavior of composite. More rough and porous the surface of the composite, more water could penetrate the composite resulting in higher water absorbency.

Effect of chitosan grafted composite on soil $\mathrm{pH}$ has been studied. Red soil had lower $\mathrm{pH}$ as compared to alluvial soil. $\mathrm{pH}$ of both alluvial and red soil began to decrease up to 90 days of incubation with 7.23 for alluvial soil and 4.8 for red soil. $\mathrm{pH}$ of alluvial and red soil differed insignificantly after 180 days of incubation. The decrease in $\mathrm{pH}$ of the chitosan composite amended soil was due to the presence of carboxylate ions in the superabsorbent which decreased the $\mathrm{pH}$ of soil slightly (Table 2). These results were in agreement with Hady et al., 2009; Bai et al., 2010 and Shahid et al., 2012.

\subsubsection{Organic Carbon content and Cation exchange capacity}

Addition of chitosan-grafted composite did not alter the organic carbon content of both red and alluvial soil. Organic carbon content was slightly decreased with soil incubation time although this reduction was insignificant. The organic carbon content of red soil was found to be less than that of alluvial soil (Table 3). Superabsorbent amended soil showed increase cation exchange capacity with an increase in the period of incubation. Initially, CEC of alluvial soil was $13.8 \mathrm{CmolP}^{+} \mathrm{Kg}^{-1}$ soil and red soil was8.5CmolP ${ }^{+} \mathrm{Kg}^{-1}$ soil. After treating the soil with chitosan grafted composite the CEC of soil was found to be increased. Highest CEC was found in composite treated soil after 180 days of incubation. After addition of chitosan-grafted composite has increased CEC of soil, it may be due to the addition of chitosangrafted composite had altered the cation-anion ratio of ion, zero point charge of soil opened up the negative sites in the soil thus cation exchange capacity of soil increased (Schneider et al., 2013). Polyacrylamide is an anionic polymer grafted on cationic chitosan. As negative charge in soil increases affect the zero-point charge of soil thus affected $\mathrm{pH}$ depended on charges in turn increased CEC of both soil. 
Table 3 Effect of polymer composite on chemical properties of soil

\begin{tabular}{|c|c|c|c|c|c|c|c|}
\hline \multirow{2}{*}{$\begin{array}{l}\text { Time } \\
\text { (Days) }\end{array}$} & \multirow{2}{*}{ Treatment } & \multicolumn{2}{|c|}{$\mathrm{pH}$} & \multicolumn{2}{|c|}{ Organic Carbon (\%) } & \multicolumn{2}{|c|}{$\begin{array}{l}\text { Cation exchange capacity } \\
(\mathrm{CEC})\left(\mathrm{C} \text { mole } \mathrm{P}^{+} \mathrm{kg}^{-1}\right)\end{array}$} \\
\hline & & Alluvial soil & Red soil & Alluvial soil & Red soil & Alluvial soil & Red soil \\
\hline \multirow{2}{*}{1} & Control & $7.73^{\mathrm{c}}$ & $5.70^{\mathrm{bc}}$ & $0.50^{\mathrm{a}}$ & $0.37^{\mathrm{a}}$ & $13.80^{\mathrm{a}}$ & $8.53^{\mathrm{a}}$ \\
\hline & Composite treated soil & $7.63^{\mathrm{bc}}$ & $5.63^{\mathrm{bc}}$ & $0.49^{\mathrm{a}}$ & $0.36^{\mathrm{a}}$ & $13.63^{\mathrm{a}}$ & $7.96^{\mathrm{a}}$ \\
\hline \multirow{2}{*}{30} & Control & $7.63^{\mathrm{bc}}$ & $5.60^{\mathrm{bc}}$ & $0.47^{\mathrm{a}}$ & $0.35^{\mathrm{a}}$ & $13.60^{\mathrm{a}}$ & $8.23^{\mathrm{a}}$ \\
\hline & Composite treated soil & $7.36^{\mathrm{ab}}$ & $5.36^{\mathrm{bc}}$ & $0.48^{\mathrm{a}}$ & $0.35^{\mathrm{a}}$ & $15.76^{\mathrm{b}}$ & $10.23^{\mathrm{b}}$ \\
\hline \multirow{2}{*}{90} & Control & $7.70^{\mathrm{bc}}$ & $5.30^{\mathrm{b}}$ & $0.45^{\mathrm{a}}$ & $0.33^{\mathrm{a}}$ & $13.93^{\mathrm{a}}$ & $8.30^{\mathrm{a}}$ \\
\hline & Composite treated soil & $7.23^{\mathrm{a}}$ & $4.80^{\mathrm{a}}$ & $0.48^{\mathrm{a}}$ & $0.35^{\mathrm{a}}$ & $15.86^{\mathrm{b}}$ & $9.30^{\mathrm{ab}}$ \\
\hline \multirow{2}{*}{180} & Control & $7.66^{\mathrm{bc}}$ & $5.26^{\mathrm{b}}$ & $0.46^{\mathrm{a}}$ & $0.34^{\mathrm{a}}$ & $14.06^{\mathrm{a}}$ & $9.26^{\mathrm{ab}}$ \\
\hline & Composite treated soil & $7.63^{\mathrm{bc}}$ & $5.26^{\mathrm{b}}$ & $0.47^{\mathrm{a}}$ & $0.36^{\mathrm{a}}$ & $16.76^{\mathrm{c}}$ & $11.73^{\mathrm{c}}$ \\
\hline
\end{tabular}

Means are the average of three replicates. Means followed by a common letter are not significantly different at the 5\% level based on Duncan's Multiple Range Test (DMRT).

Table 4 Effect of polymer composites on biological properties of soil

\begin{tabular}{|c|c|c|c|c|c|c|c|c|c|c|c|c|c|}
\hline \multirow{2}{*}{$\begin{array}{l}\text { Time } \\
\text { (Days) }\end{array}$} & \multirow{2}{*}{ Treatment } & \multicolumn{2}{|c|}{ Catalase activity } & \multicolumn{2}{|c|}{ Dehydrogenase } & \multicolumn{2}{|c|}{ Acid phosphatase } & \multicolumn{2}{|c|}{$\begin{array}{c}\text { Alkaline } \\
\text { Phosphatase }\end{array}$} & \multicolumn{2}{|c|}{ Urease activity } & \multicolumn{2}{|c|}{$\begin{array}{c}\text { Soil microbial } \\
\text { biomass carbon }\end{array}$} \\
\hline & & $\begin{array}{l}\text { Alluvial } \\
\text { soil }\end{array}$ & Red soil & $\begin{array}{l}\text { Alluvial } \\
\text { soil }\end{array}$ & Red soil & $\begin{array}{l}\text { Alluvial } \\
\text { soil }\end{array}$ & Red soil & $\begin{array}{l}\text { Alluvial } \\
\text { soil }\end{array}$ & Red soil & $\begin{array}{l}\text { Alluvial } \\
\text { soil }\end{array}$ & Red soil & $\begin{array}{l}\text { Alluvial } \\
\text { soil }\end{array}$ & Red soil \\
\hline \multirow[b]{2}{*}{ 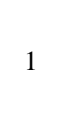 } & Control & $0.6^{\mathrm{a}}$ & $2.36^{\mathrm{a}}$ & $43.30^{\mathrm{b}}$ & $21.46^{\mathrm{b}}$ & $48.30^{\mathrm{d}}$ & $28.56^{\mathrm{b}}$ & $184.26^{\mathrm{a}}$ & $87.26^{\mathrm{a}}$ & $207.16^{\mathrm{a}}$ & $184.4^{\mathrm{f}}$ & $186.83^{\mathrm{a}}$ & $137.93^{\mathrm{b}}$ \\
\hline & $\begin{array}{l}\text { Composite } \\
\text { treated soil }\end{array}$ & $0.5^{\mathrm{a}}$ & $2.63^{\mathrm{a}}$ & $42.76^{\mathrm{b}}$ & $21.50^{\mathrm{b}}$ & $47.56^{\mathrm{d}}$ & $28.46^{\mathrm{b}}$ & $185.86^{\mathrm{a}}$ & $88.30^{\mathrm{a}}$ & $208.06^{\mathrm{a}}$ & $188.66^{\mathrm{f}}$ & $187.73^{\mathrm{a}}$ & $139.23^{\mathrm{b}}$ \\
\hline \multirow{2}{*}{30} & Control & $2.97^{\mathrm{b}}$ & $4.80^{\mathrm{a}}$ & $40.53^{\mathrm{b}}$ & $19.82^{\mathrm{ab}}$ & $53.18^{\mathrm{e}}$ & $31.75^{\mathrm{b}}$ & $237.16^{\mathrm{bc}}$ & $141.90^{\mathrm{d}}$ & $242.47^{\mathrm{b}}$ & $167.09^{\mathrm{e}}$ & $257.50^{\mathrm{d}}$ & $170.39^{\mathrm{e}}$ \\
\hline & $\begin{array}{l}\text { Composite } \\
\text { treated soil }\end{array}$ & $4^{c}$ & $8.26^{\mathrm{b}}$ & $72.26^{\mathrm{c}}$ & $21.50^{\mathrm{c}}$ & $61.06^{\mathrm{f}}$ & $45.13^{c}$ & $273.46^{\mathrm{cd}}$ & $153.70^{\mathrm{e}}$ & $278.42^{\mathrm{e}}$ & $167.56^{\mathrm{e}}$ & $252.16^{\mathrm{d}}$ & $162.51^{\mathrm{d}}$ \\
\hline \multirow{2}{*}{90} & Control & $6.77^{\mathrm{d}}$ & $15.46^{\mathrm{d}}$ & $36.06^{\mathrm{a}}$ & $19.03^{\mathrm{ab}}$ & $21.66^{\mathrm{b}}$ & $17.63^{\mathrm{a}}$ & $205.10^{\mathrm{ab}}$ & $122.23^{\mathrm{c}}$ & $244.44^{\mathrm{c}}$ & $152.96^{\mathrm{d}}$ & $232.51^{\mathrm{c}}$ & $155.32^{\mathrm{c}}$ \\
\hline & $\begin{array}{l}\text { Composite } \\
\text { treated soil }\end{array}$ & $8.5^{\mathrm{e}}$ & $23.56^{\mathrm{e}}$ & $86.70^{d}$ & $45.43^{\mathrm{d}}$ & $35.86^{\mathrm{c}}$ & $52.03^{\mathrm{c}}$ & $248.73^{\mathrm{bc}}$ & $167.56^{\mathrm{f}}$ & $253.03^{d}$ & $116.33^{\mathrm{a}}$ & $294.60^{\mathrm{e}}$ & $190.77^{f}$ \\
\hline \multirow{2}{*}{180} & Control & $8.46^{\mathrm{e}}$ & $12.23^{\mathrm{c}}$ & $33.86^{\mathrm{a}}$ & $16.60^{\mathrm{a}}$ & $15.00^{\mathrm{a}}$ & $15.43^{\mathrm{a}}$ & $182.53^{\mathrm{a}}$ & $100.93^{\mathrm{b}}$ & $237.27^{\mathrm{b}}$ & $141.13^{\mathrm{c}}$ & $214.57^{\mathrm{b}}$ & $118.90^{\mathrm{a}}$ \\
\hline & $\begin{array}{l}\text { Composite } \\
\text { treated soil }\end{array}$ & $9.53^{\mathrm{f}}$ & $16.80^{\mathrm{d}}$ & $94.63^{\mathrm{e}}$ & $70.03^{\mathrm{e}}$ & $32.03^{\mathrm{c}}$ & $72.96^{\mathrm{d}}$ & $281.60^{\mathrm{d}}$ & $176.76^{\mathrm{g}}$ & $207.16^{\mathrm{a}}$ & $126.00^{\mathrm{d}}$ & $322.90^{\mathrm{f}}$ & $221.40^{\mathrm{g}}$ \\
\hline
\end{tabular}

Means are the average of three replicates. Means followed by a common letter are not significantly different at the 5\% level based on Duncan's Multiple

Range Test(DMRT).

\subsubsection{Soil biological properties}

\subsubsection{Catalaseactivity and Dehydrogenase activity}

Catalase activity is a representative of good aerobic microbial activity in soil. Addition of chitosan-grafted composite superabsorbent improved catalase activity of soil. Chitosan grafted composite treated soil showed highest catalase activity after 180 days in alluvial soil. Red soil amended with chitosan composite showed highest catalase activity after 90 days of incubation and then decreased after 180 days of incubation in the composite (Table 4).
Dehydrogenase was found to be increased significantly with respect to time in both soils. Dehydrogenase and catalase activity represent good health of soil (Varennes et al., 2010). As chitosan and acrylamide act as a carbon source for aerobic microbes thus microbial population increases which increases enzymatic activity in soil. Dehydrogenase is an intracellular enzyme involved in the energy transfer in the respiration chain, and its activity typically occurs in all intact viable microbial cells. Thereby, its measurement is usually related to the presence of viable microorganisms and could be considered as an index of their oxidative capability (Siafu, 2017). The significant increase in dehydrogenase activity in soil samples applied with chitosan grafted composites indicated

Journal of Experimental Biology and Agricultural Sciences http://www.jebas.org 
microbes used chitosan grafted acrylamide as a carbon and nitrogen source for carrying out their metabolic activity and attacked cross linked structure converting the insoluble polymer into a soluble polymer. Thus, microbial activity increases and as a result dehydrogenase activity also increased.

\subsubsection{Alkaline and Acid Phosphatase activity}

Acid phosphatase activity was found to be highest after 30 days of incubation in composite amended alluvial soil $\left(60.06 \mu \mathrm{gkg}^{-1}\right)$. After 30 days acid phosphatase activity began to decrease in alluvial soil. Chitosan grafted amended red soil showed the highest acid phosphatase activity after 180 days of incubation i.e. $72.96 \mu \mathrm{gkg}^{-1}$. Alkaline phosphatase increased significantly in both soil with increasing period of incubation. Phosphatase enzyme is activated when there is low $\mathrm{P}$ availability in soil and phosphatase was inhibited by inorganic phosphate, which produces feedback inhibition of this enzyme. These results are in agreement with Saied et al. (2016) who reported the addition of rice straw based superabsorbent increased dehydrogenase and phosphatase activity in soil. Phosphatase activity plays an essential role in the mineralization of organic $\mathrm{P}$ and this enzyme is activated when $\mathrm{P}$ availability is low. In general, chitosan grafted composite treated soils showed significantly higher phosphatase activity than control soil suggesting a higher amount of available substrates in composite treated soils (Mahdavinia et al., 2009).

\subsubsection{Urease activity}

Urease activity was found to be decreased in both red and alluvial soil significantly. Urease activity decreased with the addition of the end product of the enzymatic reaction $\left(\mathrm{NH}_{4}{ }^{+}\right)$. The activity of this enzyme activity was impaired by polyacrylate polymers containing ammonium as a counter ion (Parvathy et al., 2014). As applied chitosan grafted polyacrylamide superabsorbent had amide as a main constituent releasing ammonium ion on decomposition. Due to this reason urease activity was decreased by application of superabsorbent. This probably resulted due to the inhibition of urease produced by the nitrogen that fabricated under conversation of $\mathrm{NH}_{4}{ }^{+}$ (Sarapatka et al., 2006; Giroto et al., 2017). Abundant microbial activity in the fertilized soil creates a big request for nitrogen and thus, higher conversion of $\mathrm{NH}_{4}{ }^{+}$, which may induce a reduction in the urease activity (Faissal et al., 2017).

\subsubsection{Soil microbial biomass carbon}

Soil microbial biomass carbon increased in both alluvial and red soil in incubation experiment. The result was found to be significant after the $3^{\text {rd }}$ month of incubation and found to be highest after sixth months of incubation. It can be due to decomposition of chitosan-grafted superabsorbent composite, after decomposition it releases $\mathrm{CO}_{2}, \mathrm{H}_{2} \mathrm{O}$ and nitrogen, providing food and energy source for the microorganism. So soil microbial biomass of superabsorbent amended soil was found to be more. The studied soil biological and biochemical parameters are connected with other soil properties. Soil organic matter is one of the important factors in soil enzyme activity (Sharma et al., 2017). Soil enzymatic activity can be sensitive biological markers and are influenced by many factors, e.g. soil moisture, temperature, aeration, $\mathrm{pH}$, organic matter quality and quantity, the presence of inhibitors and activators. Microbial biomass $\mathrm{C}$ is more sensitive than total organic $\mathrm{C}$ to indicate soil changes because it is related to soil microorganisms that are sensitive to soil variations (Sharma et al., 2017). As chitosan grafted potassium composite act as a food substrate for microbes improved microbial biomass carbon also.

\section{Conclusion}

Chitosan grafted superabsorbent altered physicochemical and biological property of soil.It improved the enzymatic activity of the soil, increases cation exchange capacity and electrical conductivity and slightly lowers the $\mathrm{pH}$ of the soil. Thus present study showed no adverse effect of chitosan-grafted composite addition on studied soil properties. Chitosan is a biopolymer and its use in superabsorbent preparation can improve various qualities of the superabsorbent composite in an eco-friendly manner. However, changes varied according to the type of soil and dominant microbes present in soil. Effect of superabsorbent composite on microbial community is needed to be study more deeply for effective use of superabsorbent composite in agriculture.

\section{Acknowledgment}

The senior author is indebted to the Indian Council of Agricultural Research, New Delhi, for granting funds in an extramural research project on "Innovative nanoclay polymer composites for the promotion of rainfed agriculture" (BHU project code M21/144).We are thankful to the Department of Chemistry, Institute of Science, BHU for FTIR and XRD analysis, CIFC,IIT, BHU for SEM and AFM study.

\section{Conflict of interests}

There is no conflict of interest.

\section{Author contribution}

This work was carried out in collaboration between all the authors. Author Nirmal De designed the study and guided in the discussion of results. Author PriyalPandey and MahendraVerma ran the experiment, generated data, managed the literature searches and produced an initial draft. All authors read and approved the final manuscript 


\section{References}

Bai C, Zhang S, Huang L, Wang H, Wang W, Ye Q (2015) Starchbased hydrogel loading with carbendazim for controlled-release and water absorption. Carbohydrate Polymers 125 376-383.

Bai W, Zhang H, Liu B, Wu Y, Song J (2010) effects of superabsorbent polymers on the physical and chemical properties of soil following different wetting and drying cycles. Soil Use Management 26: 253-260.

Bao Y, Ma J, Li Na (2011) Synthesis and swelling behaviors of sodium carboxymethyl cellulose-g-poly(AA-co-AM-co-AMPS) /MMT superabsorbent hydrogel. Carbohydrate Polymers 84 76-82.

Cannazza G, Cataldo A, De Benedetto E, DemitriC, Madaghiele M, Sannino A (2014) Experimental assessment of the use of a novel superabsorbent polymer (sap) for the optimization of water consumption in agricultural irrigation process. Water 6 2056-2069.

Casida L E, Klein D A, Santro I (1964) Soil dehydrogenase activity. Soil Science 98 371-376.

Cheng B, Pei P, Wang Z, Hu Q (2017) Advances in chitosanbased superabsorbent hydrogels. Royal Society of chemistry Advances 7: 42036-42046.

Chhonkar PK, Bhadraray S, Patra AK, Purakayastha TJ (2007) Experiments in soil biology and biochemistry, Westville publishing house, New Delhi.

FaissalA, Ouazzani N, Parrado J R, Dary M, Manyani H, Morgado BR, Barragan MD, Mandi L (2017) Impact of fertilization by natural manure on the microbial quality of soil: Molecular approach. InSaudi Journal of Biological Sciences 24: 1437-1443.

Francisco HA, Andre R F, Antonio GBP, Nagila M P S R, Judith P A F, Edvani CM (2012) Chitosan-graft-poly(acrylic acid)/rice husk ash based superabsorbent hydrogel composite: preparation and characterization. Journal of Polymer Research19:1-10. DOI 10.1007/s10965-012-0001-8.

McGarity JW, Myers MCA (1967) Survey of urease activity in soils of Northern in soils of Northern New South Wales. Plant Soil 27: 217-23.

Giroto AS, Guimaraes GGF, Foschini M, Ribeiro C (2017) Role of slow-release nanocomposite fertilizers on nitrogen and phosphate availability in soil. Scientific Reports 7: 46032-46039.

Hady E O A, El-Kader A, Shafi AM (2009) Physico-bio-chemical properties of sandy soil conditioned with acrylamide hydrogels after cucumber plantation. Australian Journal of Basic and Applied Science 3: 3145-3151.

Harrar FH, Aioua ZN, Dairi N, Hadj-Hamou AS (2014) Preparation of chitosan-g-poly (acryl amide)/montmorillonite superabsorbent polymer composites: Studies on swelling, thermal, and antibacterial Properties. Applied Polymer Science 10: 3974739761.e. DOI: 10.1002/APP.39747.

Harrar FH, Aiouaz N, Dairi N (2015) Synthesis and properties of chitosan-graft polyacrylamide/gelatin superabsorbent composites for wastewater purification. International Journal of Chemical, Molecular, Nuclear, Materials and Metallurgical Engineering 9: 849-856.

Harrar FH, Dairi N (2013) Elaboration of cellulose acetate nanobiocomposites using acidified gelatin-montmorillonite as nanofiller: Morphology, properties, and biodegradation studies. Polymer Composite 34: 1515-1524.

Jackson ML (1973) Soil chemical analysis. New Delhi, India, Prentice Hall of India Pvt. Ltd., pPp 45-47.

Jenkinson DS, Ladd JM (1981) Microbial Biomass in Soil: Measurement and Turnover. In: Paul EA, Ladd JM (Eds.), Soil Biochemistry, Dekker, New York, 415-471.

Kumar P, Choonara YE, Du LC, Modi G, Naidoo D, Pillay V (2012) Novel high-viscosity polyacrylamidated chitosan for neural tissue engineering: fabrication of anisotropic neurodurable scaffold via molecular disposition of persulfate-mediated polymer slicing and complexation. International Journal of Molecular Sciences 13: 13966-13984.

Mahdavinia GR, Mousavi SB, Karimi F, Marandi GB, Garabaghi H, Shahabvand S (2009) Synthesis of porous poly (acrylamide) hydrogels using calcium carbonate and its application for slow release of potassium nitrate. Express Polymer Letters 3: 279-285.

Nagarpita MV, Roy P, Shruthi SB, Sailaja RRN (2017) Synthesis and swelling characteristics of chitosan and CMC grafted sodium acrylate-co-acrylamide using modified nanoclay and examining its efficacy for removal of dyes. International Journal of Biological Macromolecules 102:1226-1240.

Parvathy PC, Jyothi AN, John KS, Sreekumar J (2014) Cassava starch based superabsorbent polymer as soil conditioner: impact on soil physico-chemical and biological properties and plant growth. Clean - Soil, Air, Water 42 : 1610-1617.

Said M, Atassi Y, Tally M (2018) Environmentally Friendly Chitosan-g-poly(acrylic acid-co-acrylamide)/Ground Basalt Superabsorbent Composite for Agricultural Applications Journal of Polymer Environment 26: 3937-3948. 
Saied H, Hady EOA, Basta AH, El-Dewiny CY, Abo-Sedera SA (2016) Bio-chemical properties of sandy calcareous soil treated with rice straw-based hydrogels. Journal of the Saudi Society of Agricultural Sciences15: 188-194.

Samandari S, Gazi M (2013) Removal of mercury (II) from aqueous solution using chitosan-graft-polyacrylamide semi-IPN hydrogels. Separation Science and Technology 48: 1382-1390.

Šarapatka B, Rak L, Bubenikova I (2006) The effect of hydroabsorbent on selected soil biological and biochemical characteristics and its possible use in revitalization. Ekologia (Bratislava) 25: 422-429.

Schneider A, Tesileanu R, Charles R, Sinaj S (2013) Kinetics of Soil Potassium Sorption-Desorption and Fixation. Communications in Soil Science and Plant Analysis 44: 837-849.

Shahid SA, Qidwai AA, Anwar F, Ullah I, Rashid U (2012) improvement in the water retention characteristics of sandyloam soil using a newly synthesized poly(acrylamide-coacrylicacid)/ $/ \mathrm{AlnFe}_{2} \mathrm{O}_{4}$ superabsorbent hydrogel nano-composite material. Molecules 17: 9397-9412.

Sharma J, Sukriti S, Kaith BS (2017) Fabrication of biodegradable superabsorbent using rsm design for controlled release of $\mathrm{KNO}_{3}$. Journal of polymer and Environment $26: 518-531,2017$.
Siafu SI (2017) Silicone doped chitosan-acrylamide co encapsulated urea fertilizer: an approach to controlled release fertilizers. Journal of Nanotechnology 8490730: 1-7.

Thombare N, Mishra S, Siddiqui, MZ, Jha U, Singh D, Mahajan GR (2018) Design and development of guar gumbased novel, superabsorbent and moisture retaining hydrogels for agricultural applications. Carbohydrate Polymers 185: 169-178.

Varennes A, Cunha-Queda C, Guiwei Q (2010) Amendment of an acid mine soil with compost and polyacrylate polymers enhances enzymatic activities but may change the distribution of plant species. Water Air Soil Pollution 208: 91-100.

Walkley AJ, Black CA (1934) An estimation of the Degtjareff method for determining soil organic matter and a proposed modification of the chromic acid titration method. Soil Science 37: 29-38.

Wang W, Zhang J, Wang A (2009) Preparation and swelling properties of superabsorbent nano composites based on natural guar gumandorgano- vermiculite. Applied Clay Science 46:21-26.

Zhang W, Zhang M, An S A, Lin K F, Li, H, Cui C Z, Fu RB, Zhu J (2012) The combined effect of decabromodiphenyl ether (BDE-209) and copper ( $\mathrm{Cu}$ ) on soil enzyme activities and microbial community structure. Environment Toxicology Pharmacy 34: 358-369. 